\title{
Local administration of granulocyte macrophage colony-stimulating factor induces local accumulation of dendritic cells and antigen- specific CD8+ T cells and enhances the efficacy of therapeutic vaccine in cervicovaginal tumor
}

Sung-Jong Lee ${ }^{1}, \mathrm{TC} \mathrm{Wu}^{2}$, Chien-Fu Hung ${ }^{2^{*}}$

From 30th Annual Meeting and Associated Programs of the Society for Immunotherapy of Cancer (SITC 2015) National Harbor, MD, USA. 4-8 November 2015

Immunotherapy has emerged as a promising treatment strategy for the control of HPV-associated malignancies. Various therapeutic HPV vaccines have elicited potent antigen-specific CD8+ T cell mediated antitumor immune responses in preclinical models and are currently being tested in several clinical trials. Recent evidence has reported the importance of local immune activation, and higher number of immune cells in the site of lesion correlates with positive prognosis. Granulocyte macrophage colony-stimulating factor (GMCSF) has been reported to possess the ability to induce migration of antigen presentation cells and CD8+ T cells. Therefore, in the current study, we employed a combination of systemic therapeutic HPV DNA vaccination with local GMCSF application in the TC-1 tumor. We show that intramuscular vaccination with CRT/E7 DNA followed by GMCSF intravaginal administration effectively controls TC-1 tumor in mice. Furthermore, we observe an increase in the accumulation of E7-specific CD8 + T cells and dendritic cells in the vaginal tumor following the combination treatment. In addition, we show that GMCSF induces activation and maturation in dendritic cells and promote antigen crosspresentation. Our results support the clinical translation of the combination treatment of systemic therapeutic vaccination followed by local GMCSF administration as an effective strategy for tumor treatment.

2Johns Hopkins Medical Institution, Baltimore, MD, USA

Full list of author information is available at the end of the article

\section{Authors' details}

'St. Vincent's Hospital, The Catholic University of Korea, Bethesda, MD, USA. ${ }^{2}$ Johns Hopkins Medical Institution, Baltimore, MD, USA.

Published: 4 November 2015

doi:10.1186/2051-1426-3-S2-P365

Cite this article as: Lee et al: Local administration of granulocyte macrophage colony-stimulating factor induces local accumulation of dendritic cells and antigen-specific CD8+ T cells and enhances the efficacy of therapeutic vaccine in cervicovaginal tumor. Journal for ImmunoTherapy of Cancer 2015 3(Suppl 2):P365.
Submit your next manuscript to BioMed Central and take full advantage of:

- Convenient online submission

- Thorough peer review

- No space constraints or color figure charges

- Immediate publication on acceptance

- Inclusion in PubMed, CAS, Scopus and Google Scholar

- Research which is freely available for redistribution
() Biomed Central 

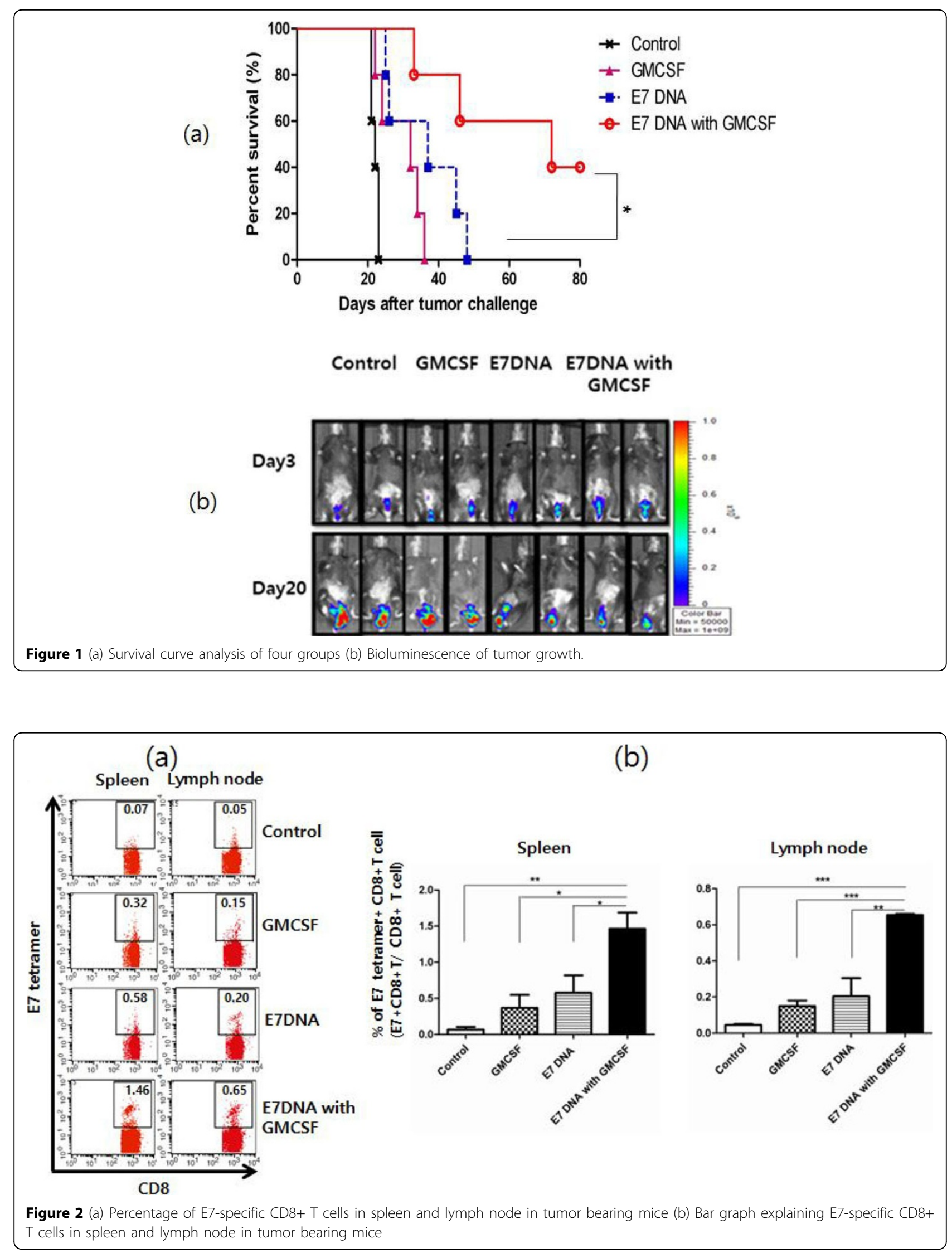

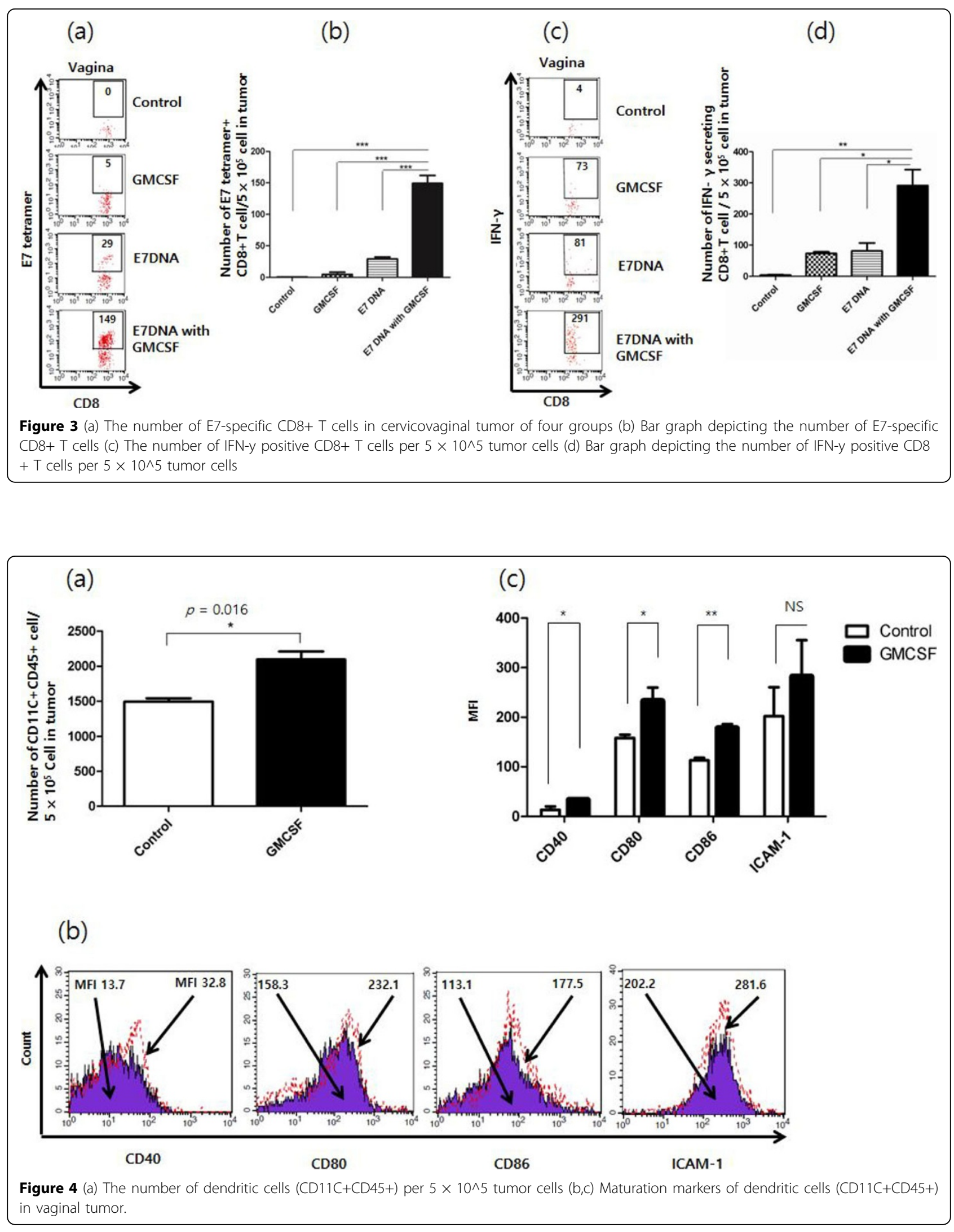


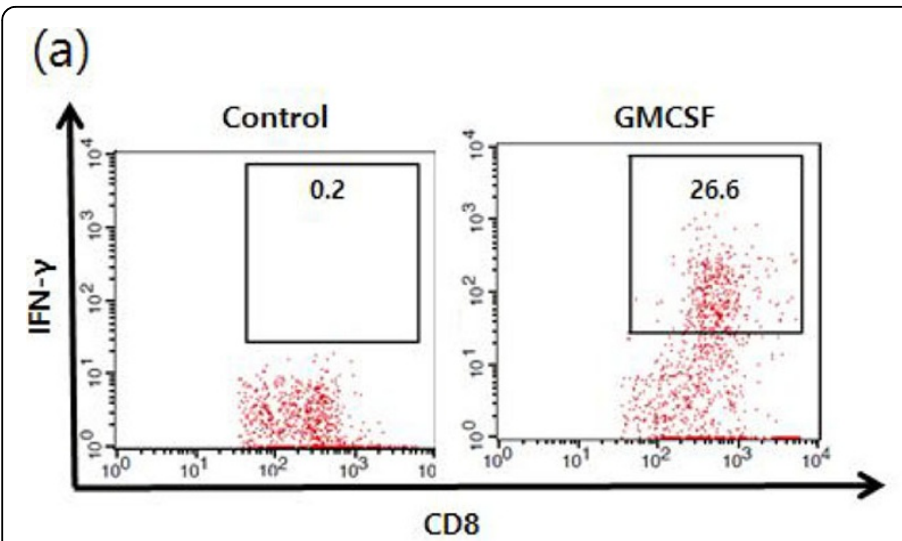

(b)

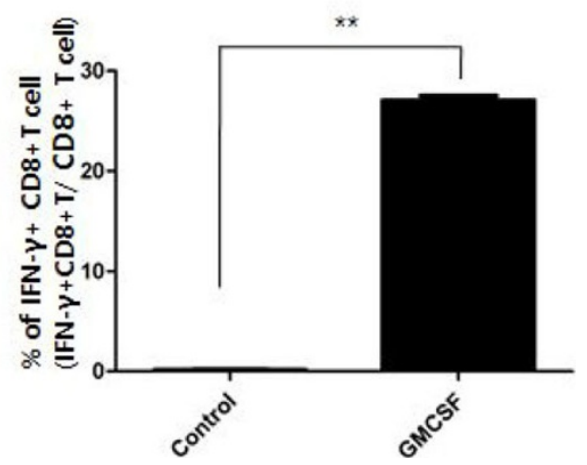

Figure $51 \times 10 \wedge 5$ E7-Specific CD8 T cell were cultured together with isolated dendritic cells in 1:1 ratio for 12 hours and stained with FITCconjugated IFN-y and APC-conjugated CD8 followed by flow cytometry analysis (a) Representative data of IFN-y staining followed by flow cytometry analysis showing the percentage of IFN-y positive CD8+ T cells (b) Bar graph depicting the percentage of IFN-y positive CD8+ T cells. 